\title{
ETIKA PROFESI AUDITOR DALAM MEMODERASI PENGARUH INDEPENDENSI DAN KOMPETENSI AUDITOR ATAS KUALITAS AUDIT
}

\author{
${ }^{1}$ Farah Latifah Nurfauziah, ${ }^{2}$ Fitria Ningrum Sayekti, ${ }^{3}$ Citra Kharisma Utami \\ ${ }_{1,2,3}$ Universitas Islam Nusantara Bandung. \\ I*farahlatifahn@uninus.ac.id, ${ }^{2}$ fitrianingrum@uninus.ac.id, ${ }^{3}$ citrakharismautami@uninus.ac.id
}

\begin{abstract}
The purpose of this study is to identify: (1) the effect of competence and independence of auditors on audit quality, (2) how auditor ethics moderates the effect of auditor competence and independence on audit quality. The sample of this study was 50 representatives of public accounting firm auditors in the city of Bandung. The validity and reliability of the questionnaire were tested before the study. The prerequisite tests for the analysis carried out were the normality test, the multicollinearity test, and the heteroscedasticity test. The data analysis method used is simple regression analysis and multiple regression analysis. The results show that $H 1$ is rejected where there is no effect of Auditor competence on Audit Quality because the regression coefficient is 0.05 and the tcount is $0.365<$ ttable 2.0452. The results of the $H 2$ test also show that there is no effect of auditor independence on audit quality because the regression coefficient is 0.222 and the tcount is $1.407<$ ttable 2.0452. While the Hla test shows that Auditor Ethics moderates the effect of Auditor competence on audit quality positively with a significance of 0.034. The H2a test shows that Auditor Ethics does not moderate the effect of Auditor independence on audit quality with a significance value of 0.399 .
\end{abstract}

Keywords: Competence, Independence, Auditor's Ethic, Audit Quality

ABSTRAK : Tujuan penelitian ini adalah untuk mengidentifikasi: (1) pengaruh kompetensi dan Independensi Auditor terhadap Kualitas Audit, (2) bagaimana Etika auditor memoderasi pengaruh kompetensi Auditor dan Independensi terhadap Kualitas Audit, Sampel penelitian ini adalah 50 perwakilan Auditor Kantor Akuntan Publik di Kota Bandung. Validitas dan reliabilitas kuesioner diuji sebelum penelitian. Uji prasyarat analisis yang dilakukan adalah uji normalitas, uji multikolonieritas, dan uji heteroskedastisitas. Metode analisis data yang digunakan adalah analisis regresi sederhana dan analisis regresi berganda. Hasil penelitian menunjukkan bahwa HI ditolak dimana tidak terdapat pengaruh kompetensi Auditor terhadap Kualitas Audit karena koefisien regresi 0,05 dan nilai thitung 0,365 < ttabel 2,0452. Hasil pengujian H2 juga menunjukkan tidak terdapat pengaruh independensi Auditor terhadap Kualitas Audit karena koefisien regresi sebesar 0,222 dan nilai thitung 1,407< ttabel 2,0452. Sedangkan pengujian H1a menunjukkan bahwa Etika Auditor memoderasi pengaruh kompetensi Auditor terhadap kualitas audit secara positif dengan signifikansi 0.034. Pengujian H2a menunjukkan bahwa Etika Auditor tidak memoderasi pengaruh independensi Auditor terhadap kualitas audit dengan nilai signifikansi 0,399 .

Kata Kunci: Kompetensi, Independensi, Etika Auditor, Kualitas Audit

\section{Pendahuluan}

Besarnya kepercayaan pengguna laporan keuangan kepada Akuntan Publik menuntut akuntan publik untuk memperhatikan kualitas auditnya. Oleh karena itu auditor harus menghasilkan audit yang berkualitas sehingga dapat mengurangi ketidakharmonisan yang terjadi antara manajemen dengan pemilik. Banyak kasus perusahaan yang "gagal" dikaitkan dengan kegagalan auditor, hal ini mengancam kredibilitas laporan keuangan. Ancaman ini semakin mempengaruhi persepsi masyarakat khususnya pengguna laporan keuangan terhadap kualitas audit (Hanjani, 2014). Kualitas audit merupakan salah satu kriteria yang digunakan untuk memastikan pelaporan keuangan dapat diandalkan. Dalam profesi akuntansi, audit memegang peranan 
penting dalam melayani masyarakat. Perannya adalah untuk meningkatkan akuntabilitas manajer dan membuat pelaporan keuangan lebih meyakinkan. Sejalan dengan perubahan dalam dunia bisnis, perubahan juga harus direspon oleh manajemen, terutama dalam melindungi kepentingan pemegang saham. Perubahan dalam akuntansi standar, pelaporan keuangan, dan audit semuanya dirancang untuk memberikan perlindungan kepada investor. Audit digunakan sebagai jaminan bagi investor yang mendasarkan kepercayaannya pada laporan keuangan. (Kuntari, Chariri, \& Nurdhiana, 2017).

Kantor akuntan publik yang bergerak di bidang jasa dan asset harus memiliki auditor yang independen dan profesional yang bertanggung jawab atas laporan audit mereka. Auditor yang bekerja harus mampu meningkatkan kinerjanya dalam memeriksa laporan keuangan untuk profesi dan memperhatikan kode etik yang berlaku. Menurut Bayu, dkk (2020), di era persaingan yang ketat seperti ini, perusahaan ingin informasi keuangan mereka berkualitas tinggi untuk publik dan investor untuk membuatnya terlihat menarik bagi investor dan pemegang saham. Dengan demikian, auditor harus dapat menjelaskan bahwa perusahaan dalam keadaan baik.

Independensi adalah karakteristik utama yang harus dimiliki seorang auditor. Auditor yang memiliki independensi tinggi tidak akan dapat dikendalikan oleh klien atau pihak lain tidak peduli seberapa besar tekanan yang mereka terima. Dengan demikian, jika independensi seorang auditor tinggi maka akan tercapai target penyelesaian tugas auditor dengan cepat dan andal.. DeAngelo (1981) dalam Tepalagul dan Lin (2015) menyatakan bahwa kualitas audit didefinisikan sebagai probabilitas bahwa (a) auditor akan mengungkap pelanggaran dan (b) melaporkan pelanggaran. Jika auditor tidak independen, akan lebih kecil kemungkinannya untuk melaporkan penyimpangan, sehingga mengganggu kualitas audit.

Kualitas selanjutnya yang perlu dimiliki oleh seorang auditor adalah kompetensinya. Kompetensi adalah pemahaman auditor tentang pemeriksaan laporan keuangan. Kompetensi dapat dikatakan sebagai rangkaian dari pengalaman dan wawasan yang dimiliki auditor. Disimpulkan bahwa semakin banyak auditor pengetahuan dan pemahaman, semakin baik kualitas audit yang dihasilkan. Standar audit menyebutkan bahwa audit harus dilakukan oleh seseorang atau lebih yang memiliki keahlian yang diperlukan dan mengikuti pelatihan teknis sebagai auditor. Disebutkan pula bahwa dalam pelaksanaan audit dan proses pembuatan laporan, seorang auditor wajib menerapkan keahlian profesionalnya secara tepat dan menyeluruh (Halim, 2015). Beberapa penelitian menunjukkan bahwa kompetensi auditor berpengaruh terhadap kualitas audit (Samsi, Riduwan, \& Suryono, 2013; Setyani, 2015). Namun, ternyata peneliti lain menyampaikan hasil yang tidak sejalan dengan hasil penelitian di atas, seperti yang disajikan oleh Indriyanto dan Nasikin (2014) yang menemukan bahwa kompetensi auditor tidak mempengaruhi kualitas audit.

Dari banyaknya kasus yang melibatkan KAP, Sebagian besar melibatkan Kantor Akuntan Publik Bereputasi yang di dalamnya beranggotakan auditor-auditor yang profesional dengan independensi dan kompetensinya. Kemudian, hal tersebut menjadi pertanyaan bagi masyarakat mengenai mengapa Kantor Akuntan Publik bereputasi tersebut dapat terlibat dalam kasus-kasus besar sehingga menurunkan kepercayaan masyarakat atas kinerja KAP dan auditor. Hal tersebut menandakan bahwa ada faktor lain yang perlu diperhatikan dalam mendukung profesionalisme baik independensi dan kompetensi auditor. Selain keharusan memiliki sikap independen dan kompeten, auditor juga harus didukung oleh perilaku etis. Ikatan Akuntan Indonesia menetapkan bahwa auditor diharapkan dapat memegang teguh etika atas profesinya (Hanjani, 2014). Sebagai tambahan atas kompetensi dan independensi, auditor juga diharuskan memiliki etika dalam mengaudit laporan keuangan. Etika itu sendiri bertujuan untuk membantu manusia bertindak secara bebas tetapi dapat dipertanggungjawabkan (Najib, 2013).

Maksud dan tujuan dari penelitian ini adalah : pertama, untuk menguji apakah kompetensi dan independensi auditor mempengaruhi kualitas audit (H1 dan $\mathrm{H} 2)$. Kedua, bagaimana peran etika auditor dalam memoderasi pengaruh kompetensi auditor dan independensi auditor terhadap kualitas audit (H1a dan H2a). Studi ini dikembangkan berdasarkan contracting theory dan teori keagenan. Contracting Theory menurut Scott (2012) digunakan untuk menjelaskan bahwa kantor akuntan terdiri dari 
sekelompok kontrak di antara berbagai kepentingan, termasuk kontrak kemitraan dengan klien, auditor junior, karyawan kantor akuntan, pemerintah, dan pihak terkait lainnya. Contracting Theory menunjukkan adanya ikatan antara auditor dan klien sebagai agen (manajemen). Auditor sebagai pihak ketiga yang independen dan dianggap kompeten, auditor diperlukan untuk mengawasi kinerja manajemen apakah telah bertindak sesuai dengan kepentingan prinsipal melalui laporan keuangan. Tugas auditor adalah memberikan opini atas akuntabilitas laporan keuangan suatu perusahaan dan mengungkapkan kelangsungan usaha yang dihadapi perusahaan jika auditor meragukan kelangsungan hidup perusahaan (Shintya, Nuryatno, \& Oktaviani, 2016).

\section{Metode Penelitian}

Dalam penelitian ini penulis menggunakan jenis penelitian deskriptif verifikatif dengan pendekatan kuantitaif yang di kaitkan dengan masalah yang ada pada objek penelitian mengenai Peran Moderasi Etika Profesi atas Pengaruh Independensi dan Kompetensi Auditor terhadap Kualitas Audit. Dalam penelitian ini, yang dijadikan populasi untuk penyebaran kuesioner adalah auditor yang bekerja di Kantor Akuntan Publik di Kota Bandung yang terdaftar di IAPI. Teknik pengambilan sampel yang dilakuka menggunakan simple random sampling (Mas'ud, 2004). Ukuran sampel ditentukan dengan menggunakan rumus slovin berdasarkan Sujarweni (2014) yaitu sebanyak 50 auditor pada Kantor Akuntan Publik di Kota Bandung yang terdaftar pada IAPI sebagai responden dalam pengisian kuisioner penelitian.

Model dalam Penelitian ini digambarkan sebagai berikut :

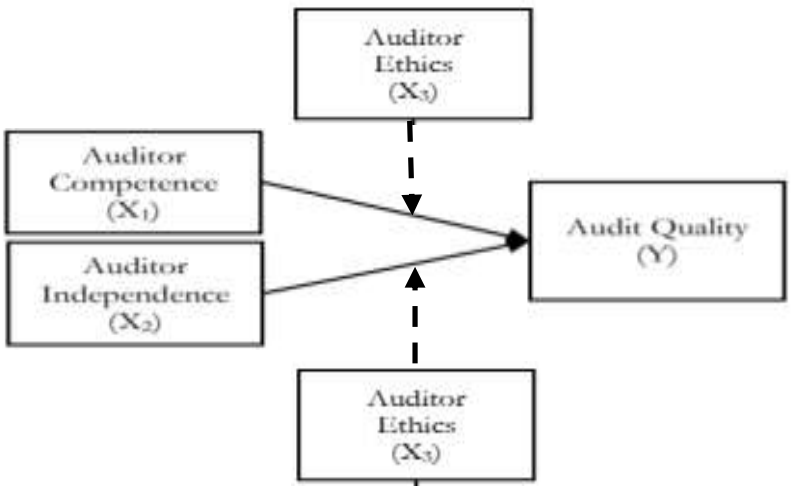

Gambar 1. Model Penelitian

Dari model penelitian di atas faktor yang membentuk penelitian ini adalah:

a. Kompetensi Auditor. Kompetensi dapat dicapai melalui pendidikan dan pengalaman. Kompetensi mampu meyakinkan pemakai bahwa kualitas jasa audit yang diberikan oleh seorang auditor dapat memenuhi tingkat profesionalisme yang tinggi. Dalam melakukan proses audit, akuntan publik harus berperan sebagai seorang ahli di bidang akuntansi dan auditing. Dengan demikian, kompetensi auditor mencakup semua pengetahuan dan pengalaman auditor yang memadai dan eksplisit untuk melakukan tindakan yang objektif, akurat, dan menyeluruh (Shintya et al., 2016). Kompetensi Auditor terdiri dari beberapa indikator-indikator yaitu Pengetahuan akan prinsip akuntansi dan standar auditing; Pengetahuan tentang jenis industri klien; Pendidikan formal yang sudah ditempuh;
Pelatihan, kursus, dan keahlian khusus yang dimiliki; Jumlah klien yang sudah diaudit; Pengalaman dalam melakukan audit; Jenis perusahaan yang pernah diaudit.

b. Independensi. Independensi adalah sikap mental yang bebas dari pengaruh, kendali orang lain, dan ketergantungan pada pihak lain (Mulyadi, 2002). Independensi Auditor terdiri dari beberapa indikator-indikator berikut: Lama Hubungan Dengan Klien (Audit Tenure); Tekanan dari Klien; Telaah dari Rekan Auditor (Peer Review); Pemberian Jasa Non Audit.

c. Etika Profesi Auditor. Dengan menjunjung tinggi etika profesi diharapkan tidak terjadi kecurangan di antara para auditor agar dapat memberikan review audit yang relevan seperti yang diharapkan oleh perusahaan. Semakin tinggi tingkat etika auditor maka semakin baik kualitas auditnya (Chrisdinawidanty, Tugiman, \& Muslih, 
2016). Etika Profesi Audit terdiri dari beberapa indikator-indikator berikut: Tanggung Jawab; Kepentingan Umum; Integritas; Objektivitas; Kompetensi dan sikap cermat kehati- hatian; Kerahasiaan; Perilaku Profesional; Standar Teknis.

d. Kualitas audit merupakan faktor penting yang harus dipegang teguh oleh seorang auditor dalam proses auditnya. Kualitas audit merupakan kemampuan auditor eksternal untuk mendeteksi kesalahan material dan bentuk penyimpangan lainnya. Kualitas audit merupakan jaminan untuk membandingkan antara kondisi nyata dan kondisi ideal (Putri, Nugraha, \& Budiyono, 2015). Kualitas Auditor terdiri dari beberapa indikator-indikator berikut: Melaporkan semua kesalahan klien; Pemahaman terhadap sistem informasi akuntansi klien; Komitmen yang kuat dalam menyelesaikan audit; Berpedoman pada prinsip auditing dan prinsip akuntansi dalam melakukan pekerjaan lapangan; Tidak percaya begitu saja terhadap pernyataan klien; Sikap hatihati dalam pengambilan keputusan.

Indikator-indikator atas variabel penelitian tersebut dituangkan ke dalam bentuk kuisioner penelitian yang kemudian akan disebarkan kepada auditor di Kota Bandung dengan jumlah sesuai dengan yang telah ditentukan. Penelitian ini di uji dengan menggunakan Teknik analisis Regresi Linear Berganda dengan variabel moderasi. Maka Persamaan Regresi dalam penelitian ini adalah sebagai berikut :

$$
\begin{gathered}
\mathrm{Y}=\mathrm{a}+\mathrm{b} 1 \mathrm{X} 1+\mathrm{b2X2}+\mathrm{b3X3}+\mathrm{b} 4 \mathrm{X} 1 \mathrm{X} 3+ \\
\mathrm{b5X2X3}+\mathrm{e}
\end{gathered}
$$

Dimana :

$$
\begin{array}{ll}
\mathrm{Y} & =\text { Kualitas Audit } \\
\mathrm{a} & =\text { Konstanta } \\
\mathrm{b}(1,2, \ldots 5) & =\text { Koefisien regresi } \\
\mathrm{X} 1 & =\text { Kompetensi } \\
\mathrm{X} 2 & =\text { Independensi } \\
\mathrm{X} 3 & =\text { Etika Auditor } \\
\mathrm{e} & =\text { Error (Error terms) }
\end{array}
$$

\section{Hasil Dan Pembahasan}

Analisis deskriptif dilakukan dalam penelitian ini dengan tujuan untuk menggambarkan berbagai karakteristik data yang digunakan dalam penelitian ini seperti mean, maksimum, minimum dan standar deviasi.

Tabel 1. Hasil uji Statistik Deskriptif

\begin{tabular}{|l|c|c|c|c|c|}
\hline \multicolumn{7}{|c|}{ Descriptive Statistics } \\
\hline & $\mathrm{n}$ & Minimum & Maximum & Mean & Std. Deviation \\
\hline Kompetensi Auditor(X1) & 50 & 117 & 170 & 147,94 & 13,264 \\
\hline Ind. Auditor (X2) & 50 & 45 & 88 & 67,94 & 11,216 \\
\hline Etika Auditor (X3) & 50 & 136 & 193 & 162,13 & 13,322 \\
\hline Kualitas Audit (Y) & 50 & 94 & 149 & 118,09 & 9,991 \\
\hline Valid N (listwise) & 50 & & & & \\
\hline
\end{tabular}

Dari tabel 1 di atas, hasil analisis menggunakan statistik deskriptif terhadap variabel kualitas audit menunjukkan nilai minimum 94 dan nilai maksimum sebesar 149 dengan rata-rata 118,09 dan nilai standar deviasi 9,991. Nilai standar deviasi lebih kecil bila dibandingkan dengan nilai rata-rata, hal ini berarti bahwa data variabel kualitas audit tersebar dengan baik. Hasil analisis menggunakan statistik deskriptif atas variabel kompetensi menunjukkan nilai minimum 117 dan nilai maksimum sebesar 170 dengan ratarata 147,94 dan nilai standar deviasi 13,264. Nilai standar deviasi lebih kecil bila dibandingkan dengan nilai rata-rata, hal ini berarti bahwa data variabel kompetensi tersebar dengan baik. Selanjutnya, hasil analisis menggunakan statistik deskriptif terhadap variabel independensi menunjukkan nilai minimum 45 dan nilai maksimum sebesar 88 dengan rata-rata 67,94 dan nilai standar deviasi 11,216. Nilai standar deviasi lebih kecil bila dibandingkan dengan nilai rata-rata, hal ini berarti bahwa data variabel independensi tersebar dengan baik. Terakhir, variabel moderasi pada penelitian ini adalah Etika Auditor. Hasil analisis menggunakan statistik deskriptif terhadap variabel etika auditor menunjukkan nilai minimum 136 dan nilai maksimum sebesar 193 dengan rata-rata 162,13 
dan nilai standar deviasi 9,991. Nilai standar deviasi lebih kecil bila dibandingkan dengan nilai rata-rata, hal ini berarti bahwa data variabel etika auditor tersebar dengan baik.

\subsection{Uji Asumsi Klasik}

Tabel 2. Hasil Uji Reliabilitas

\begin{tabular}{|l|c|c|c|}
\hline Variabel Penelitian & $\begin{array}{c}\text { Koefisien Alpha } \\
\text { Cronbach's }\end{array}$ & Syarat & Keterangan \\
\hline Kompetensi Auditor (X1) & 0,958 & 0,60 & Reliabel \\
\hline Independensi Auditor (X2) & 0,943 & 0,60 & Reliabel \\
\hline Etika Auditor (X3) & 0,958 & 0,60 & Reliabel \\
\hline Kualitas Audit (Y) & 0,957 & 0,60 & Reliabel \\
\hline
\end{tabular}

Sumber : Data Olahan SPSS (2021)

Suatu kuesioner dikatakan handal atau reliabel jika jawaban seseorang terhadap pertanyaan adalah konsisten atau stabil dari waktu ke waktu. Uji reliabilitas ini dapat dilihat dari Cronbach's alpha. Untuk dapat dikatakan suatu konstruk reliable, maka nilai Cronbach's

pengujian reliabilitas ini menggunakan bantuan program SPSS versi 2021. Dari tabel 2. diketahui bahwa semua instrumen penelitian ini reliabel, karena memiliki nilai koefisien cronbach's alpha >0,60. Berdasarkan nilai tersebut, maka instrumen-instrumen di dalam alpha harus lebih besar dari 0,6 dimana pada kuesioner dinyatakan reliabel.

Tabel 3. Hasil Uji Normalitas

\begin{tabular}{|l|l|r|}
\hline \multicolumn{2}{|c|}{ One-Sample Kolmogorov-Smirnov Test } \\
\hline \multicolumn{2}{|c|}{} & \multicolumn{1}{|c|}{$\begin{array}{c}\text { Unstandardized } \\
\text { Residual }\end{array}$} \\
\hline N & 32 \\
\hline Normal Parameters & Mean &, 0000000 \\
\cline { 2 - 3 } & $\begin{array}{l}\text { Std. } \\
\text { Deviation }\end{array}$ & 7,99688547 \\
\hline $\begin{array}{l}\text { Most Extreme } \\
\text { Differences }\end{array}$ & Absolute &, 116 \\
\cline { 2 - 3 } & Positive &, 078 \\
\cline { 2 - 3 } & Negative &,- 116 \\
\hline \multicolumn{2}{|l|}{} &, 116 \\
\hline Test Statistic &, $200^{c, d}$ \\
\hline
\end{tabular}

Sumber : Data Olahan SPSS (2021)

Uji Normalitas bertujuan untuk Menguji pada tabel 2 di atas. Dari tabel tersebut didapat apakah data tersebar secara normal atau tidak, nilai Asymptotik Significance adalah 0,200 yang Pengujian menggunakan uji statistic non- dimana lebih besar dari 0,05 yang artinya data parametrik Kolmogorov-Smirnov (K-S). Data tersebarr secara normal dan data penelitian yang tersebar normal terindikasi dari nilai memenuhi asumsi normalitas sehingga layak Asymptotik Significance $>0.05$ atau 5\%. Hasil digunakan untuk penelitian. pengujian normalitas pada penelitian ini terlihat

Tabel 4. Hasil Uji Multikolinearitas

\begin{tabular}{|c|c|c|}
\hline \multicolumn{3}{|c|}{ Coefficients $^{\mathrm{a}}$} \\
\hline \multirow{2}{*}{ Model } & \multicolumn{2}{|c|}{ Collinearity Statistics } \\
\hline & Tolerance & VIF \\
\hline (Constant) & & \\
\hline Kompetensi Auditor (X1) & ,728 & 1,374 \\
\hline Independensi Auditor (X2) & ,701 & 1,426 \\
\hline Etika Auditor (X3) & 956 & 1,046 \\
\hline
\end{tabular}

Sumber : Data Olahan SPSS (2021) 
Nilai variance inflation factor (VIF) menunjukkan bahwa tidak ada satu variabel independen yang memiliki nilai VIF lebih dari 10,0. Hasil uji multikolinearitas dapat dilihat pada tabel 4. Pada tabel di atas, dapat diketahui bahwa tiap variabel memiliki nilai toleransi mendekati angka 1 dan nilai VIF $<10,0$, maka dapat dikatakan bahwa tidak ada multikolinearitas. Antar variabel independensi auditor, kompetensi auditor, dan etika auditor juga dinyatakan bebas dan layak digunakan untuk analisis selanjutnya.

\section{Hasil Pengujian Hipotesis}

\subsection{Kompetensi Auditor Berpengaruh terhadap Kualitas Audit (H1)}

Tabel 5. Hasil Uji t1

\begin{tabular}{|c|c|c|c|c|c|c|}
\hline \multicolumn{7}{|c|}{ Coefficients $\mathbf{a}^{\mathbf{a}}$} \\
\hline & \multirow{2}{*}{ Model } & \multicolumn{2}{|c|}{$\begin{array}{c}\text { Unstandardized } \\
\text { Coefficients }\end{array}$} & \multirow{2}{*}{$\begin{array}{c}\text { Standardized } \\
\text { Coefficients }\end{array}$} & \multirow[b]{2}{*}{$\mathrm{t}$} & \multirow{2}{*}{ Sig. } \\
\hline & & $\mathrm{B}$ & Std. Error & & & \\
\hline \multirow[t]{2}{*}{1} & (Constant) & 110,683 & 20,380 & & 5,431 & ,000 \\
\hline & Kompetensi Auditor (X1) & ,050 & ,137 & ,066 & ,365 & ,718 \\
\hline
\end{tabular}

Berdasarkan hasil pengujian Tabel di atas menunjukkan bahwa nilai signifikansi pada variabel Kompetensi Auditor sebesar 0,718. Dengan demikian nilai signikansi lebih besar dari 0,05 sehingga dapat diketahui bahwa Kompetensi Auditor tidak berpengaruh terhadap kualitas audit yang berarti H1 pada penelitian ini ditolak. Pada jawaban responden yang di dapat dalam enelitian, pada variabel kompetensi terlihat bahwa tingkat capaian responden memiliki hasil yang baik. Namun, pada pertanyaan mengenai Pendidikan umum untuk mencapai kopetensi professionaldalam melakukan pemeriksaaan auditor, nilai yang di dapat rendah. Dalam SPAP, disebutkan bahwa audit harus dilaksakan oleh orang yang memiliki keahlian dan pelatihan teknis yang cukup sebagai auditor. Selain itu, dari perspektif teori atribusi, karakteristik personal seorang auditor merupakan salah satu penentu kualitas audit. Seorang auditor yang memiliki Pendidikan yang tinggi, wawasan yang luas, dan sering mengikuti pelatihan-pelatihan selama menjadi auditor merupaka dasar kompetensi auditor untuk melakukan audit untuk mecapai kulitas audit yang baik (Widiya \& Syofyan, 2020). Hasil pengujian ini sejalan dengan Indriyanto dan Nasikin (2014), Amalia dan Sarazwati (2017), Dewi dan Budiartha (2015) yang menyatakan bahwa kompetensi auditor tidak berpengaruh terhadap kualitas audit.

\subsection{Peran Moderasi Etika Auditor atas Pengaruh Kompetensi Auditor terhdapa Kualitas Audit (H1a)}

Tabel 6. Hasil Moderation Regression Analysis 1

\begin{tabular}{|c|c|c|c|c|c|c|}
\hline \multicolumn{7}{|c|}{ Coefficients ${ }^{\mathbf{a}}$} \\
\hline \multirow{2}{*}{\multicolumn{2}{|c|}{ Model }} & \multicolumn{2}{|c|}{$\begin{array}{c}\text { Unstandardized } \\
\text { Coefficients }\end{array}$} & \multirow{2}{*}{$\begin{array}{c}\begin{array}{c}\text { Standardized } \\
\text { Coefficients }\end{array} \\
\text { Beta }\end{array}$} & \multirow{2}{*}{$\mathrm{T}$} & \multirow{2}{*}{ Sig. } \\
\hline & & $B$ & Std. Error & & & \\
\hline 1 & (Constant) & 218,831 & 207,762 & & 1,053 & ,301 \\
\hline & $\begin{array}{l}\text { Kompetensi Auditor } \\
\text { (X1) }\end{array}$ & $-1,119$ & 1,448 & $-1,486$ &,- 773 & ,446 \\
\hline & Etika Auditor (X3) &,- 664 & 1,243 &,- 886 &,- 534 & ,000 \\
\hline & $\begin{array}{l}\text { Kompetensi } \\
\text { Auditor*Etika Auditor }\end{array}$ & , 007 & ,009 & 2,023 & ,829 & ,034 \\
\hline
\end{tabular}

Sumber: Data Olahan SPSS (2021) 
Dari tabel di atas, didapat nilai signifikansi atas interaksi variabel Kompetensi Auditor (X1) dan Etika Auditor (X3) adalah 0,034 dibawah 0,05 . Hal ini menunjukkan bahwa variabel moderator yaitu Etika Auditor memoderasi pengaruh kompetensi Auditor terhadap kualitas audit. Perubahan Signifikansi setelah di masuknya variabel etika auditor sebagai vaiabel moderasi menunjukkan bahwa etika auditor merupakan Pure Moderator. Nilai B yang di dapat adalah 0.008 yang artinya Variabel Moderator Etika Auditor (X3) memoderasi pengaruh kompetensi Auditor terhadap Kualitas Audit secara positif.
Hasil Penelitian ini sedikit menjawab mengenai mengapa beberapa kasus Kantor Akuntan Publik yang terindikasi memiliki auditor yang professional dengan kompetensi yang tinggi tetap terlibat dalam penyimpanganpenyimpangan. Kell, dkk (2002) menyatakan bahwa etika berkaitan dengan pertanyaan mengenai bagaimana seseorang berperilaku terhadap sesamanya. Maryani dan Ludigdo (2001) mengartikan bawah etika merupakan seperangkat aturan dan norma atau pedoman yang mengatur perilalku manusia baik yang harus dilakukan maupun yang tidak boleh dilakukan oleh manusia, masyarata, ataupun profesi.

\subsection{Independensi Auditor Berpengaruh terhadap Kualitas Audit (H2)}

\begin{tabular}{|c|c|c|c|c|c|c|}
\hline \multicolumn{7}{|c|}{ Coefficients ${ }^{\mathbf{a}}$} \\
\hline \multirow{2}{*}{\multicolumn{2}{|c|}{ Model }} & \multicolumn{2}{|c|}{$\begin{array}{l}\text { Unstandardized } \\
\text { Coefficients }\end{array}$} & \multirow{2}{*}{$\begin{array}{c}\begin{array}{c}\text { Standardized } \\
\text { Coefficients }\end{array} \\
\text { Beta }\end{array}$} & \multirow{2}{*}{$\mathrm{T}$} & \multirow{2}{*}{ Sig. } \\
\hline & & $\mathrm{B}$ & Std. Error & & & \\
\hline \multirow[t]{2}{*}{1} & (Constant) & 103,039 & 10,842 & & 9,503 & ,000 \\
\hline & $\begin{array}{l}\text { Independensi } \\
\text { Auditor (X2) }\end{array}$ & ,222 & ,158 & ,249 & 1,407 & , 170 \\
\hline
\end{tabular}

Berdasarkan hasil pengujian tabel di atas menunjukkan bahwa nilai signifikansi pada variabel independensi Auditor sebesar 0,170. Dengan demikian nilai signikansi lebih besar dari 0,05 sehingga dapat diketahui bahwa Independensi Auditor tidak berpengaruh terhadap kualitas audit yang berarti $\mathrm{H} 2$ pada penelitian ini ditolak. Hali ini bertolak belakang dengan pernyataan Standar Umum Auditing yang menyatakan bahwa "Dalam semua hal yang berhubungan dengan perikatan, independensi, dalam sikap mental harus dipertahankan oleh auditor". Hal ini bisa jadi disebabkan oleh masih adanya intervensi manajemen dalam penyusunan dalam pelaksanaan program audit yang menyebabkan sikap independensi auditor melemah. Penelitian ini sejalan dengan penelitian sebelumnya yang dilakukan oleh Amalia dan Sarazwati (2017).

\subsection{Peran Moderasi Etika Auditor atas Pengaruh Independensi Auditor terhadap Kualitas Audit (H2a)}

Tabel 6. Hasil Moderation Regression Analysis 2

\begin{tabular}{|c|c|c|c|c|c|c|}
\hline \multicolumn{7}{|c|}{ Coefficients $^{\mathbf{a}}$} \\
\hline \multirow{2}{*}{\multicolumn{2}{|c|}{ Model }} & \multicolumn{2}{|c|}{$\begin{array}{c}\text { Unstandardized } \\
\text { Coefficients }\end{array}$} & \multirow{2}{*}{$\begin{array}{c}\text { Standardized } \\
\text { Coefficients }\end{array}$} & \multirow{2}{*}{$\mathrm{T}$} & \multirow{2}{*}{ Sig. } \\
\hline & & $\mathrm{B}$ & Std. Error & & & \\
\hline \multirow[t]{3}{*}{1} & (Constant) & 123,442 & 111,943 & & 1,103 & 280 \\
\hline & $\begin{array}{l}\text { Independensi Auditor } \\
\text { (X2) }\end{array}$ & $-1,058$ & 1,616 & $-1,187$ &,- 655 & ,518 \\
\hline & Etika Auditor (X3) &,- 159 & ,676 &,- 212 &,- 235 & ,816 \\
\hline
\end{tabular}




\begin{tabular}{|l|l|l|l|l|l|}
\hline $\begin{array}{l}\text { Independensi } \\
\text { Auditor*Etika Auditor }\end{array}$ &, 008 &, 010 & 1,584 &, 399 \\
\hline
\end{tabular}

Dari tabel di atas, didapat nilai signifikansi atas interaksi variabel Independensi Auditor (X1) dan Etika Auditor (X3) adalah 0,399 dibawah 0,05. Hal ini menunjukkan bahwa variabel moderator yaitu Etika Auditor tidak memoderasi pengaruh kompetensi Auditor terhadap kualitas audit. Tidak berubahnya Signifikansi setelah di masuknya variabel etika auditor sebagai vaiabel moderasi menunjukkan bahwa etika auditor merupakan Homologiser Moderator. Hasil poenelitian ini sejalan dengan penelitian Suharti dan Arpriyanti (2019) yang menyatakn bahwa etika auditor bukanlah variabel moderator atas hubungan independensi auditor dan kualitas audit.

\section{Kesimpulan}

Dari hasil penelitian yang sudah dilakukan dapat disimpulkan bahwa secara parsial, kompetensi dan independensi auditor tidak berpengaruh terhadap kualitas audit. Pada mengujian variabel moderasi, etika auditor hanya memoderasi pengaruh kompetensi auditor terhadap kualitas audit. Namun, tidak memoderasi pengaruh independensi auditor terhadap kualitas audit. Berdasarkan hal tersebut diharapkan bagi auditor, disamping meningkatkan kompetensi, juga memperhatika kode etik audit selama menjalankan tugasnya.

\section{DAFTAR PUSTAKA}

Amalia, D., \& Sarazwati, R. Y. (2017). FaktorFaktor Yang Mempengaruhi Kualitas Audit Intern. Jurnal Akuntansi Dan Bisnis, 17(2), 132-143. Retrieved from www.jab.fe.uns.ac.id

Ayu, D., Dewi, C., \& Ketut Budiartha, I. (2015). Pengaruh Kompetensi Dan Independensi Auditor Pada Kualitas Audit Dimoderasi Oleh Tekanan Klien. 1, 197-210.

Bayu, M. D. M., Wayan, R. N., \& ... (2020). Audit quality: A review based on auditor ethics, competence, independence, and client pressure on audit quality. ... Conference of Innovation ..., (325), 283-297. Retrieved from http://ejournal.unmas.ac.id/index.php/ICISTSD/arti cle/view/2234

Boynton, Johnson, \& Kell. (2002). NoModern Auditing. Jakarta: Erlangga.

Chrisdinawidanty, Tugiman, H., \& Muslih, M. (2016). Pengaruh etika auditor dan audit fee terhadap kualitas audit (studi kasus pada kantor akuntan publik di wilayah Bandung). E-Proceeding OfManagement, 3(3), 34663474.

Halim, A. (2015). Auditing (Dasar-dasar Audit Laporan Keuangan) (5th ed.). Yogyakarta: UPP STIM YKPN.

Hanjani, A. (2014). Pengaruh Etika Auditor, Pengalaman Auditor, Fee Audit, Dan Motivasi Auditor Terhadap Kualitas Audit (Studi pada Auditor KAP di Semarang). Diponegoro Journal of Accounting, 3(2), 111-119.

Indriyanto, A. R., \& Nasikin. (2014). Analisa faktor-faktor yang mempengaruhi kualitas audit yang dilakukan oleh Badan Pemeriksa Keuangan Republik Indonesia (Studi kasus pada BPK RI Perwakilan Provinsi Kepulauan Bangka Belitung). Jurnal Ilmiah Mahasiswa FEB, 2(4), 326-340.

Kuntari, Y., Chariri, A., \& Nurdhiana. (2017). The Effect of Auditor Ethics, Auditor Experience, Audit Fees and Auditor Motivation on Audit Quality. Sriwijaya International Journal of Dynamic Economics And Business, 1(2), 203-218.

Maryani, T., \& Ludigdo, U. (2001). Survei Atas Faktor-faktor yang Mempengaruhi Sikap dan Perilaku Etis Akuntan. TEMA, 2(1), 4962.

Mas'ud, F. (2004). Survei diagnosis organisasional: konsep dan aplikasi. Semarang: Badan Penerbit Universitas Diponegoro.

Mulyadi. (2002). Auditing (6th ed.). Jakarta: Salemba Empat.

Najib, A. D. R. (2013). Pengaruh keahlian, independensi, dan etika terhadap kualitas audit: Studi pada auditor pemerintah di BPKP Perwakilan Provinsi Sul-Sel. Universitas Hassanudin.

Putri, D. I., Nugraha, N., \& Budiyono, I. (2015). Analisis pengaruh independensi, kompetensi, dan ukuran kantor akuntan publik terhadap kualitas audit (studi kasus pada auditor kantor akuntan publik di kota Semarang). In In Seminar Nasional Terapan Riset Inovatif (Sentrinov). Semarang.

Samsi, N., Riduwan, A., \& Suryono, B. (2013). Pengaruh pengalaman kerja, independensi, dan kompetensi terhadap kualitas audit: Etika auditor sebagai variabel pemoderasi. 
Jurnal Ilmu Dan Riset Akuntansi, 1(2), 207226.

Scott, W. R. (2012). Financial Accounting theory (6th ed.). Canada: Pearson.

Setyani, R. (2015). Pengaruh kompetensi, independensi, etika, motivasi, dan time budget pressure auditor terhadap kualitas audit (Studi empiris pada auditor pemerintah di Inspektorat Kabupaten Boyolali) (Universitas Muhammadiyah Surakarta). Retrieved from http://eprints.ums.ac.id/37567/

Shintya, A., Nuryatno, M., \& Oktaviani, A. A. (2016). Pengaruh kompetensi, independensi, dan tekanananggarana waktu terhadap kualitas audit. In Seminar Nasional
Cendekiawan ke 2. Jakarta.

Sujarweni, W. (2014). Metode Penelitian: Lengkap, Praktis, dan Mudah Dipahami. Yogyakarta: Pustaka baru Press.

Tepalagul, N., \& Lin, L. (2015). Auditor Independence and Audit Quality: A Literature Review. Journal of Accounting, Auditing and Finance, 30(1), 101-121. https://doi.org/10.1177/0148558X14544505

Widiya, W., \& Syofyan, E. (2020). Pengaruh Kompetensi, Independensi, Dan Etika Auditor Terhadap Kualitas Audit Aparat Inspektorat (Studi Empiris pada Kantor Inspektorat Provinsi Sumatera Barat). Jurnal Eksplorasi Akuntansi, 2(4), 3737-3754. 